\title{
ANALISIS PENGARUH WORK-LIFE BALANCE DAN PENGEMBANGAN KARIR TERHADAP KEPUASAN KERJA KARYAWAN PT.TELKOMSEL, TBK BRANCH MALANG
}

\author{
Uki Yonda Asepta \\ Dosen Universitas Ma Chung Malang \\ Sekar Harumi Putri Maruno \\ Alumni Universitas Machung
}

\begin{abstract}
ABSTRAK
Karyawan merupakan sebuah aset bagi perusahaan. Karyawan memiliki peran yang sangat penting bagi perusahaan untuk mencapai tujuan perusahaan. Dalam mempertahankan kinerja karyawan agar tetap produktif maka perlu memperhatikan kepuasan kerja pada karyawan. Kepuasan kerja seorang karyawan di dalam organisasi tidak lepas dari pengembangan karir, dan work-life balance. Penelitian ini dilakukan untuk mengetahui pengaruh Work-life balance dan Pengembangan Karir terhadap Kepuasan Kerja. Jenis penelitian ini menggunakan metode kuantitatif kausal. Data yang digunakan dalam penelitian ini adalah data primer diperoleh dari kuesioner yang disebarkan kepada 30 responden karyawan PT. Telkomsel,Tbk Branch Malang. Teknik pengumpulan sampel yang digunakan adalah sensus. Metode analisis data yang digunakan adalah regresi linier berganda. Hasil dari penelitian ini menunjukkan bahwa Work-life balance dan Pengembangan Karir berpengaruh secara simultan terhadap Kepuasan Kerja Karyawan. Secara parsial, work-life balance berpengaruh secara signifikan terhadap kepuasan kerja karyawan. Pengembangan karir berpengaruh secara signifikan terhadap kepuasan kerja karyawan, akan tetapi dapat diketahui bahwa kedua variabel bebas tersebut yang paling dominan pengaruhnya terhadap kepuasan kerja karyawan adalah work-life balance.
\end{abstract}

Kata-kata Kunci: work-life balance, pengembangan karir, kepuasan kerja karyawan, organisasi.

\begin{abstract}
Employee is an asset to the company. Employees have a very important role for companies to achieve corporate goals. To keep employee performance to remain productive then it is necessary. Job satisfaction of an employee within the organization can't be separated from career development, and work life balance. This research was conducted to determine the effect of Work-life Balance and Career Development on Job Satisfaction. This type of research uses a causal quantitative method. The data used for the research is primary data obtained from questionnaires distributed to 30 respondents employees of PT. Telkomsel, Tbk Branch Malang. The sampling technique used was the census. Data analysis method used is multiple linear regression. The results of research indicate that Work-Life Balance and Career Development affect simultaneously to Employee Satisfaction. Partially, work life balance significantly to employee job satisfaction. Career development has a significant effect on employee job satisfaction, will be falling again. The most dominant effect on employee job satisfaction is the work balance.

Keywords: work-life balance, career development, job satisfaction, organization
\end{abstract}

\section{PENDAHULUAN}

Karyawan merupakan sebuah aset bagi perusahaan. Karyawan memegang peran utama dalam menjalankan roda kehidupan perusahaan. Untuk tercapainya suatu tujuan dalam perusahaan diperlukan Sumber Daya Manusia (SDM) yang memadai, yang sesuai dengan persyaratan dalam perusahaan, dan juga harus mampu menjalankan tugas-tugas yang telah ditentukan oleh perusahaan. Apabila karyawan memiliki produktivitas dan motivasi kerja yang tinggi, maka akan menghasilkan kinerja dan pencapaian yang baik bagi perusahaan. Dalam mempertahankan kinerja karyawan agar tetap produktif maka perlu memperhatikan kepuasan kerja pada karyawan. Ketika seorang merasakan kepuasan dalam bekerja tentunya ia akan berupaya semaksimal mungkin dengan segenap kemampuan yang dimilikinya untuk menyelesaikan tugas pekerjaannya. Dengan demikian produktivitas dan hasil kerja karyawan akan meningkat secara optimal. Menurut Hasibuan (2007) kepuasan kerja adalah keadaan emosional yang menyenangkan atau sikap umum terhadap perbedaan penghargaan yang diterima dan yang seharusnya diterima. Kepuasan kerja dipengaruhi beberapa faktor yaitu balas jasa yang adil dan layak, penempatan yang sesuai dengan keahlian, berat ringannya pekerjaan, suasana dan lingkungan kerja, peralatan yang menunjang pelaksanaan pekerjaan, sikap pemimpin dan kepemimpinan dan sifat pekerjaan yang monoton atau tidak. 
Kepuasan kerja seorang karyawan di dalam organisasi tidak lepas dari pengembangan karir, dan work-life balance. Keseimbangan antara kehidupan pribadi dan kehidupan kerja tersebut disebut dengan work-life balance. Menurut Lockwood (2003) Work-life balance adalah suatu keadaan seimbang pada dua tuntutan di mana pekerjaan dan kehidupan seorang individu adalah sama. Work-life balance dalam pandangan karyawan adalah pilihan mengelola kewajiban kerja dan pribadi atau tanggung jawab terhadap keluarga. Sedangkan dalam pandangan perusahaan work-life balance adalah tantangan untuk menciptakan budaya yang mendukung di perusahaan di mana karyawan dapat fokus pada pekerjaaan mereka sementara di tempat kerja.

Pada umumnya jam kerja karyawan adalah 8 jam dalam sehari. Namun deadline tugas yang diberikan oleh perusahaan menyebabkan karyawan harus berkerja lebih dari 8 jam dalam sehari, sehingga karyawan harus menggunakan jam lembur (overtime) untuk menyelesaikannya. Pekerja dituntut untuk melaksanakan pekerjaannya dengan maksimal akan tetapi terkadang perusahaan mengesampingkan keseimbangan kehidupan-kerja karyawan yang dilakukannya untuk perusahaan seperti misalnya target penyelesaian tugas yang mendesak sehingga terkadang harus kerja lembur (overtime), rapat kerja hingga larut malam, serta perjalanan bisnis ke luar kota yang akhirnya membuat kebutuhan dengan keluarga, lingkungan, maupun pemenuhan untuk pribadi jadi terganggu. Seringkali perusahaan memberikan jumlah tugas atau pekerjaan yang berlebihan yang mengakibatkan menurunnya produktivitas kerja pada karyawan. Hal tersebut menunjukkan bahwa seorang individu mengalami kesulitan untuk menyeimbangkan antara kehidupan pribadinya dan pekerjaannya. Ini menunjukkan bahwa worklife balance pada suatu perusahaan sangatlah penting. Perusahaan harus memperhatikan keseimbangan antara kehidupan pribadi dan kehidupan kerja karyawannya agar kepuasan kerja pada karyawan tetap terjaga.

Faktor lain yang berpengaruh terhadap kepuasan kerja adalah pengembangan karir. Perencanaan dan pengembangan karir yang jelas dalam organisasi dapat meningkatkan motivasi kerja karyawan dalam melaksanakan pekerjaannya, sehingga menciptakan rasa puas dalam melaksanakan pekerjaannya (Nugroho \& Kunartinah, 2012).

Dikutip dari Jobstreet (2014) Badan Pusat Statistik Nasional Indonesia melakukan survey terhadap pengangguran yang ada di Indonesia bahwa jumlah penganguran di negeri ini berkisar di angka 7,2 juta. Adapun sebesar $85 \%$ responden dari survey mengaku kalau mereka tidak memiliki keseimbangan antara pekerjaan dan kehidupan pribadi atau work-life balance. Menurut hasil penelitian oleh Redwood (2009) di Inggris mengemukakan bahwa perusahaan yang mengusahakan karyawan untuk memiliki worklife balance akan menghasilkan pendapatan tahunan $20 \%$ lebih baik daripada perusahaan yang tidak mendorong keseimbangan baik antara pekerjaan dan kehidupan pribadi. $60 \%$ responden mengaku tidak memiliki pengembangan karir, 54\% disebabkan karena karyawan bekerja tidak sesuai dengan latar belakangnya, 53\% menyatakan bahwa karyawan tidak puas dengan karakter atasannya.

Dikutip dari selular.id (2016) yang merilis hasil analisis tingkat kepuasan karyawan perusahaan telekomunikasi di Indonesia terhadap gaji dan tunjangan mereka dengan membandingkan sepuluh sampel perusahaan telekomunikasi (Telkom, Telkomsel, Indosat, XL Axiata, Smartfren, Telkom Akses, Huawei, Telkom Sigma, Ericsson dan Biznet). Dari kesepuluh perusahaan telekomunikasi Telkomsel menempati posisis teratas dengan tingkat kepuasan karyawan yaitu sebesar $(3,9)$, menyusul di belakangnya adalah Ericsson $(3,8)$, Telkom $(3,7)$, XL $(3,6)$, Biznet (3,5), Indosat $(3,3)$, diikuti oleh Smartfren, Huawei, dan Telkom Sigma yang sama-sama mendapatkan rating 3,2 serta Telkom Akses dengan rating 3,1.

PT. Telkomsel,Tbk adalah perusahaan unggulan yang bergerak dibidang Telekomunikasi selular dan merupakan perusahaan milik BUMN PT. Telkomsel,Tbk memiliki konsumen yang cukup banyak dan mengklaim sebagai perusahaan telekomunikasi terbesar di Indonesia. Untuk mempertahankan posisi PT. Telkomsel,Tbk dalam persaingan global perusahaan yang bergerak di bidang telekomunikasi lainnya, karyawan PT. Telkomsel,Tbk dituntut untuk profesional dan harus bisa meningkatkan produktivitas kerjanya. Tuntutan dari pekerjaan tersebut membuat karyawan perusahaan harus pandai menyeimbangkan kehidupan pribadi dan kerjanya. Selain itu, perusahaan harus memperhatikan kepuasan kerja pada karyawan PT. Telkomsel,Tbk.

PT. Telkomsel,Tbk menerapkan worklife balance dengan memberikan fasilitas seperti mushola untuk karyawan beragama muslim menjalankan ibadah dan pantry bagi karyawan untuk selingan ketika karyawan merasa jenuh, serta memberikan makan siang bagi karyawan.

Dari uraian latar belakang di atas maka dilakukan penelitian dengan mengangkat suatu topik tentang "Analisis Pengaruh Work-life balance dan 
Pengembangan Karir Terhadap Kepuasan Kerja PT. Telkomsel,Tbk,Tbk Branch Malang”.

\section{Tujuan Penelitian}

Adapun tujuan dari penelitian sebagai berikut:

1. Menganalisis apakah Work-life balance berpengaruh pada kepuasan kerja karyawan PT. Telkomsel,Tbk,Tbk Branch Malang.

2. Menganalisis apakah pengembangan karir berpengaruh pada kepuasan kerja karyawan PT. Telkomsel,Tbk, Tbk Branch Malang.

\section{LANDASAN TEORI}

\section{Work-life balance}

Menurut Lockwood (2003) work-life balance adalah suatu keadaan seimbang pada dua tuntutan dimana pekerjaan dan kehidupan seorang individu adalah sama. Dimana work-life balance dalam pandangan karyawan adalah pilihan mengelola kewajiban kerja dan pribadi atau tanggung jawab terhadap keluarga. Menurut Greenhaus et al. (2003) keseimbangan kehidupan-kerja adalah sejauh mana suatu individu terikat secara bersama di dalam pekerjaan dan keluarga, dan sama-sama puas dengan peran dalam pekerjaan dan peran dalam keluarganya.

Indikator-indikator untuk mengukur keseimbangan kehidupan-kerja menurut McDonald dan Bradley (2005) yaitu:

1. Keseimbangan waktu

Menyangkut jumlah waktu yang diberikan untuk bekerja dan berkegiatan di luar pekerjaan. Keseimbangan waktu adalah jumlah waktu yang dialokasikan oleh karyawan pada pekerjaan maupun kehidupan pribadi mereka dengan keluarga (Ramadhani, 2012). Keseimbangan waktu adalah cara yang dapat anda lakukan untuk menyeimbangkan waktu anda untuk kegiatan belajar atau bekerja, bersenang-senang atau bersantai, dan beristirahat secara efektif. Jika dapat menyeimbangkan waktu diharapkan hasilnya adalah konsentrasi anda akan meningkat, organisasi waktu anda akan lebih baik, produktifitas akan meningkat dan yang terpenting tingkat stress anda akan berkurang.

\section{Keseimbangan keterlibatan}

Tingkat keterlibatan psikologis dan komitmen dalam bekerja atau di luar pekerjaan. Keseimbangan keterlibatan adalah karyawan dapat menikmati waktu dan terlibat secara fisik dan emosional dalam kegiatan sosialnya. Contohnya waktu karyawan dihabiskan selama 8 jam setiap harinya di kantor dan tersisa 5 jam untuk keluarga, apabila selama 5 jam tersebut karyawan dapat menikmati waktu dan terlibat secara fisik dan emosional dalam kegiatan sosialnya, maka keseimbangan keterlibatan akan tercapai.

3. Keseimbangan kepuasan
Berhubungan dengan tingkat kepuasan kerja pada saat bekerja dan hal-hal di luar pekerjaan. Keseimbangan kepuasan adalah kepuasan dari diri sendiri yang timbul apabila karyawan menganggap apa yang dilakukannya selama ini cukup baik dan dapat mengakomodasi kebutuhan pekerjaan maupun keluarga. Hal ini dilihat dari kondisi yang ada pada keluarga, hubungan dengan teman-teman maupun rekan kerja, serta kualitas dan kuantitas yang diselesaikan.

\section{Pengembangan Karir}

Menurut Samsudin (2006) pengembangan karir adalah suatu usaha meningkatkan kemampuan teknis, teoritis, konseptual, dan moral karyawan sesuai dengan kebutuhan pekerjaan/ jabatan melalui pendidikan dan latihan. Menurut Nawawi (2005) pengembangan karir adalah suatu rangkaian (urutan) posisi atau jabatan yang ditempati seseorang selama masa kehidupan tertentu. Pengertian ini menempatkan posisi/jabatan seseorang pekerja di lingkungan suatu organisasi/perusahaan, sebagai bagian rangkaian dari posisi/jabatan yang ditempatinya selama masa kehidupannya. Menurut Handoko (2001) karir adalah semua pekerjaan jabatan yang ditangani atau dipegang selama kehidupan kerja seseorang.

Indikator-Indikator pengembangan karir menurut Wahyudi (2002), diantaranya:

1. Penilaian dan Evaluasi: penilaian dan evaluasi yang dilakukan mengenai pelaksanaan pengembangan karir telah berjalan efektif sesuai dengan aturan yang berlaku, sehingga dapat diketahui hasilnya.

2. Prestasi Kerja: kegiatan paling penting untuk memajukan karir adalah prestasi kerja yang tinggi, maka kemajuan karir karyawan.

3. Latar Belakang Pendidikan: latar belakang pendidikan diperhatikan oleh manajemen dalam proses kenaikan pangkat/jabatan sesuai persyaratan dan kemampuan karyawan.

4. Pelatihan yang telah diikuti: pelatihan yang terprogram dilaksanakan dalam rangka pengembangan karir, berjalan sesuai dengan aturan yang berlaku.

5. Pengalaman Kerja: pengalaman kerja dijadikan dasar dalam menentukan pengembangan karir, sehingga berpengaruh terhadap pengembangan karir karyawan.

6. Kesetian pada Perusahaan: kesetian pada perusahaan dijadikan dasar dalam menentukan kemajuan karir seseorang.

\section{Kepuasan kerja}

Kepuasan kerja pada dasarnya merupakan sesuatu yang bersifat individual. Setiap individu memiliki tingkat kepuasan yang berbeda-beda sesuai 
dengan sistem nilai yang berlaku pada dirinya. Makin tinggi penilaian terhadap kegiatan dirasakan sesuai dengan keinginan individu, maka makin tinggi kepuasannya terhadap kegiatan tersebut. Kepuasan kerja mempengaruhi tingkat kedisiplinan karyawan, artinya jika kepuasan diperoleh dari pekerjaan, maka kedisiplinan karyawan baik. Sebaliknya jika kepuasan kerja kurang tercapai dalam pekerjaannya maka kedisiplinan karyawan rendah. Menurut Suwatno (2001) Kepuasan kerja adalah merupakan suatu kondisi psikologis yang menyenangkan atau perasaan karyawan yang sangat subyektif dan sangat tergantung pada individu yang bersangkutan dan lingkungan kerjanya, dan kepuasan kerja merupakan suatu konsep multificated (banyak dimensi), ia dapat mewakili sikap secara menyeluruh atau mengacu pada bagian pekerjaan seseorang. Sedangkan Husein (2005) berpendapat bahwa kepuasan kerja adalah penilaian atau cerminan dari perasaan pekerja terhadap pekerjaannya. Hal ini tampak dalam sikap positif pekerja terhadap pekerjaannya dan segala sesuatu yang dihadapi lingkungan pekerjaannya. Siagian (2005) berpendapat bahwa kepuasan kerja merupakan suatu cara pandang seseorang, baik yang bersifat positif maupun bersifat negatif, tentang pekerjaannya. Banyak faktor yang perlu mendapat perhatian dalam menganalisis kepuasan kerja seseorang. Berbagai penelitian telah membuktikan bahwa apabila dalam pekerjaannya seseorang mempunyai otonomi untuk bertindak, terdapat variasi, memberikan sumbangan penting dalam keberhasilan organisasi dan karyawan memperoleh umpan balik tentang hasil pekerjaan yang dilakukannya, yang bersangkutan akan merasa puas. Bentuk program perkenalan yang tepat serta berakibat pada diterimanya seseorang sebagai anggota kelompok kerja, situasi lingkungan berakibat pada tingkat kepuasan kerja yang tinggi.

Indikator yang digunakan untuk mengukur kepuasan kerja menurut Robbins (2007):

a. Kepuasan terhadap Gaji

Gaji merupakan upah yang diperoleh seseorang sebanding dengan usaha yang dilakukan dansama dengan upah yang diterima oleh orang lain dalam posisi yang sama.

b. Kepuasan terhadap Pekerjaan Itu Sendiri Sejauh mana pekerjaan menyediakan kesempatan seorang untuk belajar memperoleh tanggung jawab dalam suatu tugas tertentu dan tantangan untuk pekerjaan yang menarik.

c. Kepuasan terhadap Sikap Atasan

Sejauh mana perhatian bantuan teknis dan dorongan ditunjukkan oleh supervisor terdekat terhadap bawahan. Atasan yang memiliki hubungan personal yang baik dengan bawahan serta mau memahami kepentingan bawahan memberikan kontribusi positif bagi kepuasan pegawai, dan partisipasi bawahan dalam pengambilan keputusan memberikan dampak positif terhadap kepuasan pegawai.

d. Kepuasan terhadap Rekan Kerja

Tingkat dimana rekan kerja pandai secara teknis dan mendukung secara sosial. Bagi kebanyakan pegawai, kerja merupakan salah satu cara untuk memenuhi kebutuhan interaksi sosial. Oleh karena itu mempunyai rekan kerja yang menyenangkan dapat meningkatkan kepuasan kerja.

e. Kepuasan terhadap Promosi

Mengacu pada sejauh mana pergerakan atau kesempatan maju diantara jenjang berbeda dalam organisasi. Keinginan untuk promosi mencakup keinginan untuk pendapatan yang lebih tinggi, status sosial, pertumbuhan secara psikologis dan keinginan untuk rasa keadilan.

\section{Hipotesis Penelitian}

Hipotesis adalah dugaan sementara atau jawaban sementara dan masih harus dibuktikan kebenarannya (Sugiyono, 2009). Berdasarkan rumusan masalah yang telah dikemukakan sebelumnya, maka peneliti merumuskan hipotesis sebagai berikut:

H1: Work-life balance berpengaruh terhadap Kepuasan kerja karyawan.

H2: Pengembangan karir berpengaruh terhadap Kepuasan kerja karyawan.

Hipotesis ini berdasarkan penelitian terdahulu Ganapathi \& Gilang (2016) yang menyatakan bahwa work-life balance yang terdiri dari keseimbangan waktu, keseimbangan keterlibatan dan keseimbangan kepuasan kerja yang berpengaruh secara parsial dan simultan. Dan berdasarkan penelitian terdahulu oleh Putri dan Kusumastuti (2014) dengan judul "Pengaruh Pengembangan Karir terhadap Kepuasan Kerja Pegawai Tetap Direktorat Human Resource Development di Kantor Pusat PT. Pertamina (Persero)" yang menyatakan bahwa pengembangan karir memiliki pengaruh yang positif dan signifikan terhadap kepuasan kerja pegawai tetap Direktorat Human Resource Development di Kantor Pusat PT. Pertamina (Persero).

\section{Model Penelitian}

Berikut adalah model penelitian dalam penelitian ini, variabel X1 (work-life balance) dan X2 (pengembangan karir) berpengaruh terhadap variabel Y (kepuasan kerja karyawan). 


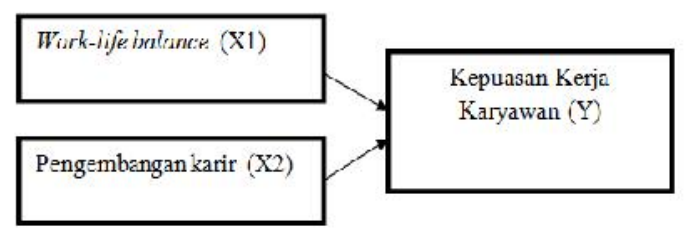

\section{Gambar 1. Model Penelitian}

\section{METODE PENELITIAN}

Jenis Penelitian

Penelitian ini merupakan penelitian Kuantitatif yaitu penelitian yang berupa angka-angka dan analisis menggunakan statistik. Penelitian kuantitatif bertujuan untuk menunjukkan hubungan antar variabel, menguji teori, dan mencari generalisasi yang mempunyai nilai prediktif. Sedangkan jenis penelitiannya ini dikategorikan sebagai penelitian kausal komparatif. Penelitan kausal kompartif adalah merupakan penelitian yang berupaya untuk menciptakan hubungan sebab akibat. Menurut Husein (2012) desain kausal digunakan untuk mengukur kuat hubungan dan pengaruh antar variabel dalam penelitian.

\section{Variabel dan Definisi Operasional Variabel}

Penelitian ini menggunakan dua variabel, yaitu variabel independen dan variabel dependen. Menurut Sugiyono (2011) variabel independen atau variabel bebas merupakan variabel yang mempengaruhi atau yang menjadikan sebab perubahannya atau timbulnya variabel dependen (terikat). Merupakan sebab yang diperkirakan dari beberapa perubahan dalam variabel terikat biasanya dinotasikan dengan simbol X. (X1) work-life balance dan (X2) pengembangan karir.

Variabel dependen atau terikat merupakan variabel yang dipengaruhi atau yang menjadi akibat, karena adanya variabel bebas. Keberadaan variabel ini dalam penelitian kuantitatif adalah sebagai variabel yang dijelakan dalam fokus topik penelitian, disimbolkan dengan (Y) yaitu kepuasan kerja.

Berikut merupakan tabel dari variabel dan definisi operasional variabel.

Tabel 1. Definisi Operasional

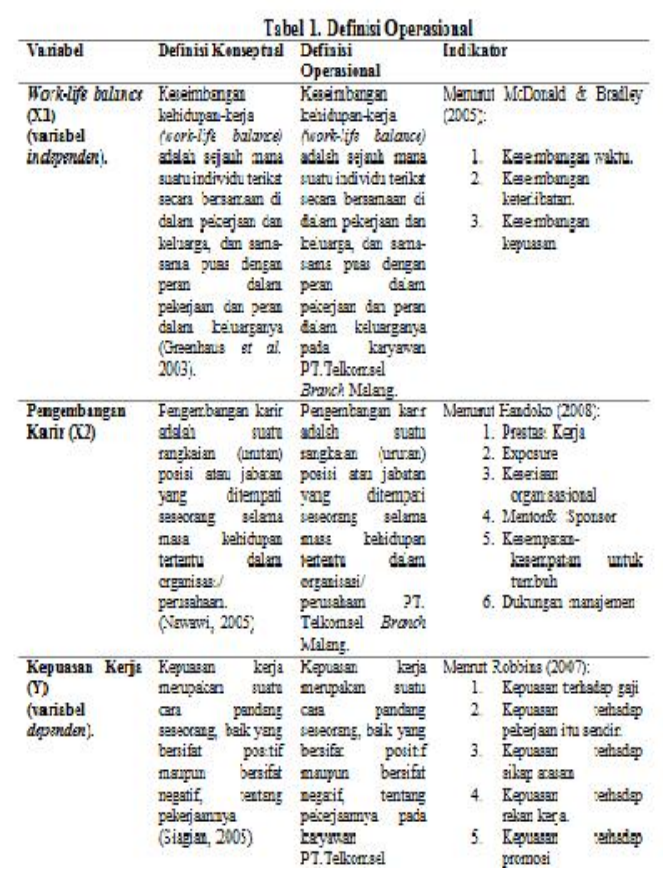

Data, Sumber Data, dan Pengumpulan Data

Sumber data yang digunakan dalam penelitian ini adalah data primer. Menurut Narimawati (2008) Data primer adalah data yang berasal dari sumber asli atau pertama. Data yang diperoleh secara langsung dari sumber data didapat dari hasil kuesioner yang diberikan kepada seluruh staff PT.Telkomsel,Tbk Branch Malang.

Teknik pengumpulan data yang digunakan dalam penelitian ini adalah penyebaran kuesioner. Menurut Riduwan (2010) angket adalah daftar pertanyaan yang diberikan kepada orang lain yang bersedia memberikan respon sesuai dengan permintaan pengguna. Teknik penyebaran kuesioner dipilih karena lebih mudah untuk mengumpulkan data dari sampel yang berjumlah banyak dan lebih efesien dalam penghematan waktu.

Kuesioner yang digunakan dalam penelitian ini adalah kuesioner tertutup menggunakan skala pengukuran interval dengan model Skala Likert. Menurut Sugiyono (2007) skala Likert digunakan untuk mengukur sikap, pendapat dan presepsi seseorang atau kelompok orang tentang fenomena sosial. Jawaban dari skala likert mempunyai gradasi dari sangat positif sampai dengan negatif. Bobot nilai setiap responden dijumlahkan sehingga diperoleh skor total. Skala ini biasanya menggunakan skala 1-5 yang memiliki nilai ujung yang menyatakan sangat setuju dan sangat tidak setuju (Malhotra dan Peterson, 2006).

Populasi dan Sampel

Populasi adalah keseluruhan subjek penelitian (Arikunto, 2006). Sedangkan populasi menurut 
Sugiono (2003) adalah wilayah generalisasi yang terdiri atas subjek atau objek oleh peneliti untuk dipelajari dan kemudian ditarik kesimpulanya. Populasi pada perusahaan telkomsel berjumlah 47 orang yang terbagi menjadi 2 yaitu karyawan organik dan non organik. Karyawan organik merupakan karyawan tetap perusahaan PT.Telkomsel,Tbk yang berjumlah 30 orang, sedangan non organik merupakan karyawan outsourcing berjumlah 17 orang. Pada penelitian ini menggunakan populasi seluruh staff organik yang ada pada PT.Telkomsel,Tbk Branch Malang. Total keseluruhan staff organik yang ada pada PT. Telkomsel,Tbk Branch Malang adalah 30 orang, sehingga populasi dalam penelitian ini 30 orang.

Metode yang digunakan dalam penarikan sampel ini adalah sampling jenuh atau sensus. Pengertian dari sampling jenuh atau sensus menurut Sugiyono (2008), sampling jenuh atau sensus adalah teknik penentuan sampel bila semua anggota populasi digunakan sebagai sampel. Sehingga sampel dalam penelitian ini adalah jumlah keseluruhan staff yang ada pada perusahaan PT.Telkomsel Branch Malang yaitu 30 responden. Menurut Bailey (1999) penelitian yang menggunakan analisis data dengan statistik, ukuran sampel paling minimum adalah 30 responden.

Teknik Analisis Data

Teknik analisis data yang digunakan adalah regresi linier berganda. Regresi linear berganda ditujukan untuk menentukan hubungan linear antar beberapa Variabel bebas yang biasa disebut $\mathrm{X} 1, \mathrm{X} 2, \mathrm{X} 3$, dan seterusnya dengan variabel terikat yang disebut $Y$ (Situmorang, 2008). Model persamaannya adalah sebagai berikut:

$\mathrm{Y}=\alpha+\beta 1 \mathrm{X} 1+\beta 2 \mathrm{X} 2+\mathrm{e}$

Keterangan:

$\mathrm{Y}=$ Kepuasan kerja karyawan

$\alpha=$ Konstanta

$\mathrm{X} 1$ = Work-life balance

$\mathrm{X} 2$ = Pengembangan karir

$\beta 1, \beta 2, \beta 3=$ Koefisien Regresi

$\mathrm{e}=\operatorname{error}($ pengganggu $)$

\section{HASIL}

Dalam penelitian ini menggunakan data primer degan obyek penelitian PT.Telkomsel,Tbk Branch Malang.

\section{Uji Hipotesis Simultan (F Test)}

Pengujian secara simultan digunakan untuk mengetahui apakah hasil dari analisis regresi signifikan atau tidak, dengan kata lain model yang diduga tepat/sesuai atau tidak. Jika hasilnya signifikan, maka Ho ditolak dan $\mathrm{Ha}$ diterima. Sedangkan jika Hasilnya tidak signifikan, maka
Ho diterima dan Ha ditolak. Hal ini dapat juga dikatakan sebagai berikut:

Ho ditolak jika F hitung > F Tabel

Ha diterima jika $F$ hitung $<$ F Tabel

Tabel 2 F Test

\begin{tabular}{|c|c|c|c|c|c|}
\hline Wote! & Sulf of of Syapres & $D j$ & Wean Soura? & $F$ & Sig \\
\hline Regresion & 1338.570 & $?$ & 659.485 & .9000 & $\sin$ \\
\hline Reridtal & 1.003.837 & 27 & 33.775 & & \\
\hline loinl & 224.200 & $2 y$ & & & \\
\hline
\end{tabular}

Berdasarkan Tabel di atas nilai $\mathrm{F}$ hitung sebesar 19,999. Sedangkan F Tabel $(\alpha=0.05$; db regresi $=2: \mathrm{db}$ residual $=27$ ) adalah sebesar 3,354. Karena F hitung > F Tabel yaitu 19,999>3,354 atau nilai sig $F(0,000)<\alpha=0.05$ maka model analisis regresi adalah signifikan. Hal ini berarti Ho ditolak dan Ha diterima sehingga dapat disimpulkan bahwa variabel terikat (Kepuasan kerja karyawan (Y)) dapat dipengaruhi secara signifikan oleh variabel bebas (Work-life balance (X1), Pengembangan karir (X2)).

Uji Hipotesis Parsial ( $t$ Test)

$\mathrm{t}$ test digunakan untuk mengetahui apakah masing-masing variabel bebas secara parsial mempunyai pengaruh yang signifikan terhadap variabel terikat. Dapat juga dikatakan jika $\mathrm{t}$ hitung $>\mathrm{t}$ Tabel atau -t hitung < -t Tabel maka hasilnya signifikan dan berarti Ho ditolak dan Ha diterima. Sedangkan jika $\mathrm{t}$ hitung $<\mathrm{t}$ Tabel atau -t hitung > -t Tabel maka hasilnya tidak signifikan dan berarti Ho diteima dan $\mathrm{Ha}$ ditolak.

\section{Tabel 3. UJI t Test}

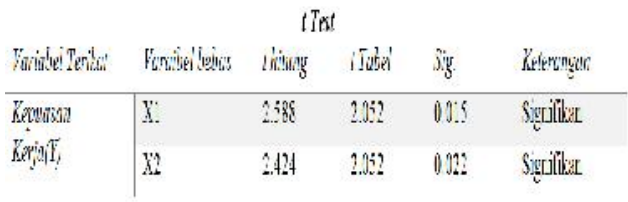

Berdasarkan Tabel 3 diperoleh Hasil sebagai berikut :

1. $\mathrm{t}$ test antara X1 (Work-life balance) dengan $\mathrm{Y}$ (Kepuasan kerja karyawan) menunjukkan $\mathrm{t}$ hitung $=2,588$. Sedangkan $\mathrm{t}$ Tabel $(\alpha=0.05 ; \mathrm{db}$ residual $=27)$ adalah sebesar 2,052. Karena t hitung $>\mathrm{t}$ Tabel yaitu 2,588 $>2,052$ atau nilai sigs $\mathrm{t}(0,015)<\alpha=0.05$ maka pengaruh $\mathrm{X} 1$ (Work-life balance) terhadap kepuasan kerja karyawan adalah signifikan. Hal ini berarti Ho ditolak dan Ha diterima sehingga dapat disimpulkan bahwa kepuasan kerja karyawan dapat dipengaruhi secara signifikan oleh work-life balance atau dengan meningkatkan work-life balance maka kepuasan kerja karyawan akan mengalami peningkatan secara nyata. 
2. $\quad \mathrm{t}$ test antara (X2) pengembangan karir dan kepuasan kerja karyawan (Y) t hitung 2,424. Karena t hitung > t Tabel yaitu 2,424 >2,052 atau nilai sig $\mathrm{t}(0,022)<\alpha=0.05$ maka pengaruh $\mathrm{X} 2$ (pengembangan karir) terhadap kepuasan kerja karyawan adalah signifikan pada alpha 5\%. Hal ini berarti Ho ditolak dan Ha diterima sehingga dapat disimpulkan bahwa kepuasan kerja karyawan dapat dipengaruhi secara signifikan oleh pengembangan karir atau dengan meningkatkan pengembangan karir maka kepuasan kerja karyawan akan mengalami peningkatan secara nyata.

Dari Hasil keseluruhan dapat disimpulkan bahwa variabel bebas mempunyai pengaruh yang signifikan terhadap kepuasan kerja karyawan secara simultan dan parsial. Diketahui bahwa kedua variabel bebas tersebut yang paling dominan pengaruhnya terhadap kepuasan kerja karyawan adalah work-life balance karena memiliki nilai koefisien beta dan $\mathrm{t}$ hitung paling besar.

\section{PEMBAHASAN}

Work-life balance berpengaruh terhadap kepuasan kerja karyawan. Hal ini sejalan dengan hasil penelitian dari Ganipathi dan Gilang (2016) yang menyatakan berdasarkan hasil pengujian parsial dengan variabel work-life balance yang diwakilkan dengan indikator keseimbangan kepuasan berpengaruh secara signifikan terhadap kepuasan kerja.

Namun perusahaan perlu
memperhatikan lagi pada kondisi ruangan kerja pada karyawan. Hal ini berdasarkan dari jawaban reponden mengenai kondisi ruang kerja karyawan yang membuat nyaman pada karyawan memiliki rata-rata yang paling rendah. Dikutip dari Kompasiana.com (2015) rasa aman dan nyaman merupakan hal yang sangat penting untuk diperhatikan dalam suatu lingkungan kerja karena kondisi kualitas lingkungan yang baik akan memberikan rasa nyaman dan sehat yang mendukung kinerja dan produktivitas manusia. Kualitas lingkungan kerja yang baik dan sesuai dengan kondisi manusia sebagai pekerja akan mendukung kinerja dan produktivitas kerja yang dihasilkan. Oleh karena itu lingkungan kerja harus ditangani dan atau didesain sedemikian sehingga menjadi kondusif terhadap pekerja untuk melaksanakan kegiatan dalam suasana yang aman dan nyaman. Evaluasi lingkungan dilakukan dengan cara pengukuran kondisi tempat kerja dan mengetahui respon pekerja terhadap paparan lingkungan kerja.

Jobstreet.co.id (2013) menulis bahwa di Singapura pemerintah mendukung permintaan masyarakatnya yang menginginkan work-life balance dalam kehidupan mereka, bahkan sistem work-life balance mulai diterapkan di beberapa departemen pemerintahan seperti waktu bekerja sesuai batas. Setelah beberapa waktu hasil penerapan work-life balance menunjukkan hal yang positif, produktivitas meningkat, pengeluaran berkurang dikarenakan angka keluar masuk karyawan berkurang, angka absen semakin menurun dan komitmen karyawan kepada perusahaan pun semakin tinggi. Hal ini dapat menjadi catatan untuk para pelaku usaha dan jajaran manajemen perusahaan bahwa jika mereka bersedia untuk menerapkan work-life balance kepada karyawannya di tempat kerja maka perusahaan tersebut akan menjadi lebih menyenangkan, efisien, dan produktif.

Sedangkan di Indonesia Belum banyak perusahaan yang melihat ketidakseimbangan antara work and life sebagai isu. Namun dengan perkembangan jaman dan teknologi yang cukup pesat, Generasi Milenial (Gen Y) sudah mulai sadar akan isu ini. Kepentingan personal dan keluarga sering konflik dengan tuntutan pekerjaan dan profesional. Alhasil banyak orang merasa bahwa hidup berjalan di luar kontrol mereka. Kondisi burn-out dan tingkat turnover yang tinggi menjadi salah satu akibat dari ketidakseimbangan antara work dan life. Bagi perusahaan, isu ini menjadi penting ketika ketidakseimbangan work dan life menyebabkan turunnya produktivitas dan efisiensi kerja karyawan. Menurut hasil penelitian the American Sociological Review (2014) konflik antara pekerjaan dan keluarga tidak sepenuhnya merupakan masalah individual namun juga bisa diselesaikan secara sistematis dengan sedikit manajemen kepemimpinan dalam perusahaan. Maka, Human Resource harus mulai memperhatikan isu ini baik untuk diri sendiri maupun untuk perusahaan. Komitmen untuk menyeimbangkan kehidupan kerja dengan kehidupan pribadi harus dimulai dari dua belah pihak. HR bisa melakukan langkah untuk mendorong perkembangan budaya yang mengutamakan respect dan trust dalam perusahaan. Menjadi sangat penting bagi perusahaan untuk mengetahui kebutuhan karyawan yang berbeda-beda dan mengadopsi pendekatan-pendekatan HR yang bisa mendorong keberhasilan work-life balance karyawan dalam perusahaan. Bisa dengan mencoba menggunakan "employee engagement survey" atau survei simpel untuk menanyakan feedback karyawan. Setelah mengetahui kebutuhan karyawan bisa mulai memetakan kebutuhan mana yang bisa dipenuhi dan selaras dengan tujuan perusahaan. Inisiatif sederhana seperti adanya ruangan menyusui, jam kerja yang lebih fleksibel bagi para orang tua, tersedianya makan siang dari perusahaan, atau 
sesederhana pantry untuk karyawan bisa menjadi awalan bagus untuk menunjukkan bahwa perusahaan peduli pada karyawan dan ingin mereka mendapatkan work-life balance (Karir.com, 2016). Kompasiana.com (2013) menanggapi bahwa beberapa orang berpendapat work-life balance adalah tentang keseimbangan di dalam pikiran dan jiwa, bukanlah keseimbangan fisik dan waktu. Bukan sekedar "bagi-bagi waktu" antara urusan kerja dan keluarga atau kerja dan urusan spiritual atau antara kerja dan urusan diri sendiri. Jika menganut prinsip WLB sebagai prinsip bagi waktu maka tak akan pernah bisa "adil". WLB adalah tentang manajemen diri dan wisdom diri.

Dalam beberapa paparan mengenai isuisu work-life balance seperti di atas dapat disimpulkan bahwa work-life balance dapat dibangun dengan mengefektifkan penggunaan waktu pada masing-masing individu kemudian didukung oleh perusahaan dengan melihat worklife balance berdasarkan kebutuhan karyawan seperti ruang kerja yang nyaman seperti apa yang dibutuhkan oleh karyawan.

Pengembangan karir berpengaruh terhadap kepuasan kerja karyawan. Hal ini selaras dengan penelitian Kurniawan (2015) yaitu Pengembangan Karir berpengaruh signifikan terhadap Kepuasan Kerja secara parsial.

Namun perusahaan perlu
memperhatikan lagi latar belakang pendidikan karyawan, hal tersebut berdasarkan rata-rata terendah dari jawaban responden mengenai latar belakang pendidikan karyawan mempengaruhi pengembangan karir di PT. Telkomsel. Menurut penelitian yang dilakukan oleh Wibowo (2012) menyatakan bahwa latar belakang pendidikan dan pengalaman kerja karyawan menentukan kualitas dan kuantitas kinerja karyawan. Semakin tinggi latar belakang pendidikan dan pengalaman kerja seseorang, maka orang tersebut memiliki tingkat pengetahuan dan keterampilan yang lebih dibandingkan dengan seseorang yang tidak memiliki latar belakang pendidikan serta pengalaman kerja. Pengetahuan juga mencangkup kemampuan untuk memahami dan menerapkan informasi pada tanggung jawab pekerjaan. Sedangkan keterampilan merujuk pada kemampuan fisik yang dibutuhkan untuk mencapai atau menjalankan suatu tugas atau pekerjaan. Maka dari itu, tingkat pengetahuan dan keterampilan yang dimiliki seseorang yang memiliki latar belakang pendidikan dan pengalaman kerja yang lebih tinggi diharapkan mampu menghasilkan kinerja yang lebih baik.

\section{KESIMPULAN DAN SARAN}

Kesimpulan
Penelitian ini dilakukan untuk
mengetahui variabel mana sajakah yang mempunyai pengaruh pada Kepuasan Kerja Karyawan. Dalam penelitian ini variabel bebas yang digunakan adalah variabel Work-life balance dan Pengembangan Karir sedangkan variabel terikat yang digunakan adalah Kepuasan Kerja Karyawan.

Hasil pada penelitian menunjukkan bahwa:

1. Work-life balance berpengaruh secara positif terhadap kepuasan kerja karyawan di PT. Telkomsel,Tbk Branch Malang. Semakin baik work-life balance karyawan dengan memperhatikan keseimbangan kepuasan yang ada maka semakin baik pula kepuasan kerja yang diperoleh oleh perusahaan dan karyawan.

2 . Pengembangan karir berpengaruh secara positif terhadap kepuasan kerja karyawan pada PT. Telkomsel,Tbk Branch Malang.

3. Work-life balance dan pengembangan karir memiliki pengaruh yang signifikan terhadap Kepuasan Kerja Karyawan secara simultan.

Saran

Adapun saran-saran yang dapat dikemukakan dari hasil penelitian dan pembahasan adalah sebagai berikut:

1. Diharapkan pihak perusahaan dapat mempertahankan work-life balance pada karyawan, karena variabel work-life balance mempunyai pengaruh yang dominan dalam mempengaruhi kepuasan kerja karyawan diantaranya yaitu memperhatikan kenyamanan pada kondisi ruang kerja karyawan dengan mempertimbangkan beberapa hal diantaranya layaknya bangunan, tata letak ruang kantor sudah sesuai dengan kebutuhan karyawan atau belum sesuai, dan konsep tatanan ulang pada ruangan karyawan. Dengan mempertimbangkan hal-hal tersebut maka dapat meningkatkan work-life balance dengan keseimbangan kepuasan.

2. Kesempatan pengembangan karir dan pelatihan kepada karyawan lebih ditingkatkan dengan memberikan pendidikan dan pelatihan yang lebih sesuai dengan yang dibutuhkan oleh karyawan tersebut agar membantu karyawan dalam menggali potensi yang sudah dimiliki, sehingga pelatihan yang diberikan menunjang pengembangan karir pada karyawan. Seperti pelatihan motivasi untuk memotivasi karyawan agar berprestasi dan selalu berusaha meningkatkan kinerjanya dengan begitu maka karyawan dapat pertimbangan untuk naik jabatan atau memiliki pengembangan karir.

3. Mengingat variabel bebas dalam penelitian ini merupakan hal yang sangat penting dalam mempengaruhi kepuasan kerja karyawan diharapkan hasil penelitian ini dapat dipakai sebagai acuan bagi peneliti selanjutnya untuk 
mengembangkan penelitian ini dengan mempertimbangkan variabel-variabel lain diluar variabel yang sudah masuk dalam penelitian ini.

\section{DAFTAR PUSTAKA}

1. Akdon \& Riduwan. (2010). Rumus dan Data Dalam Analisis Statistika. Cet 2. Bandung: Alfabeta.

2. Arikunto, S. (2006). Prosedur Penelitian Suatu Pendekatan Praktek. Cetakan Ketigabelas. Jakarta: Rineka Cipta.

3. Bailey, D. K. (1999). Methods of Social Research. New York: the Free Press.

4. Ganapathi, D. M. I., \& Gilang, A. (2016). Pengaruh Work-life Balance Terhadap Kepuasan Kerja Karyawan (Studi pada PT. Bio Farma Persero). Ecodemica, Vol. IV No.1.

5. Greenhaus, H. J., Collins, M. K., \& Shaw, D. J. (2003). The Relation Between WorkFamily Balances and Quality Of Life. Journal of Vocational Behaviour Vol.63 pp: 510-531.

6. Handoko, T. H. (2001). Manajemen Personalia dan Sumber daya Manusia. Edisi Kedua.Yogyakarta: BFE.

7. Hasibuan, M. (2007). Manajemen Sumber Daya Manusia. Jakarta: Haji Mas Agung.

8. Husein, U. (2005). Riset Sumber daya manusia dalam organisasi. Jakarta: Gramedia.

9. Husein, U. (2012). Metode Penelitian untuk Skripsi dan Tesis. Jakarta: Rajawali.

10. JobStreet. (2013). Bekerja Sesuai Batas. Diakses pada 13 Mei 2017 www.Jobstreet.co.id.

11. JobStreet. (2014, Mei). 73\% Karyawan Tidak Puas dengan Pekerjaan Mereka. Diakses pada 9 Maret 2017 www.Jobstreet.co.id.

12. Kompasiana. (2013). Work-life Balance Menciptakan Etos Kerja yang Unggul. Diakses pada 13 Mei 2017 www.Kompasiana.com.

13. Kompasiana. (2015). Pengaruh Kebisingan, Temperatur, dan Pencahayaan Terhadap Performa Kerja. Diakses pada 5 Mei 2017 www.Kompasiana.com.

14. Lockwood, N. R. (2003). Work/Life Balance: Challenges and Solutions. Research Quaterly, 1-10.

15. Lockwood, N. R. (2003). Work/Life Balance: Challenges and Solutions. Research Quaterly, 1-10.

16. Malhotra, N., \& Peterson. (2006). Basic Marketing Research: A Decision-Making Approach. (2nd ed). New Jersey: Pearson Education, Inc.

17. McDonald, P., \& Bradley, L. M. (2005). The Case for Work/Life Balance: Closing the Gap Between Policy and Practice. 20:20 Series 15.

18. Nawawi, H. H. (2005). Manajemen Sumber Daya Manusia untuk Bisnis yang
Kompetitif. Yogyakarta: Gajah Mada University Press.

19. Nirmawati, U. (2008). Metodologi Penelitian Kualitatif dan Kuantitatif: Teori dan Aplikasi. Bandung: Agung Media.

20. Nugroho, D., \& Kunartinah. (2012). Analisis Pengaruh Kompensasi dan Pengembangan Karier terhadap Kepuasan Kerja dengan Mediasi Motivasi Kerja. Jurnal Bisnis dan Ekonomi Vol.19, No.2.

21. Redwood, M. (2009). The Impact of Work-life balance and Family Friendly Human Resource Policies on Employees Job Satisfaction. Dissertation. United States: Nova Southeastern University.

22. Robbins, S. (2007). Perilaku Organisasi. Jakarta: Salemba Empat.

23. Samsudin, S. (2006). Manajemen Sumber Daya Manusia. Cetakan ke1. Bandung: Pustaka Setia.

24. Seluler. (2016). Soal Gaji dan Tunjangan Karyawan, Telkomsel Paling Tinggi. Diakses pada 17 Maret 2017 www.seluler.id

25. Siagian, S. P. (2005). Organisasi Kepemimpinan dan Perilaku Administrasi. Jakarta: Haji Mas Agung.

26. Situmorang, H. (2008). Filasafat Ilmu dan Metode Riset. Medan: Usu Press.

27. Sugiyono. (2003). Metode Penelitian Bisnis. Bandung: Pusat Bahasa Depdiknas.

28. Sugiyono. (2008). Metode Penelitian Kunatitatif Kualitatif dan $R \& D$. Bandung:Alfabeta.

29. Sugiyono. (2009). Metode Penelitian Bisnis (Pendekatan Kuantitatif,Kualitatif, dan R\&D).Bandung: Alfabeta.

30. Sugiyono. (2011). Metode Penelitian Kuantitatif dan $R \& D$. Bandung: Alfabeta.

31. Suwatno. (2001). Asas-asas Manajemen. Bandung: Suci Press

32. Wahyudi, B. (2002). Manajemen Sumber Daya Manusia. Bandung: Sulita.

33. Wibowo. (2012). Manajemen Kinerja (Edisi ke 3). Jakarta: Rajawali Pers. 